\title{
SKRINING FITOKIMIA EKSTRAK ETANOL MIKROALGA Spirulina platensis YANG BERPOTENSI SEBAGAI ANTIBAKTERI
}

\author{
Suratno \\ Program Studi D-3 Analis Kesehatan, Fakultas Ilmu Kesehatan, \\ Universitas Muhammadiyah Palangkaraya \\ e-mail : nono.suratno89@yahoo.com
}

\begin{abstract}
ABSTRAK
Pencarian bahan alam yang mengandung senyawa golongan antibakteri masih perlu dilakukan. Mikroalga diketahui memproduksi metabolit intraseluler dan ekstraseluler yang memiliki aktivitas biologi seperti antibakteri, misalnya Spirulina platensis. Penelitian ini bertujuan untuk: (1) mengetahui golongan senyawa metabolit sekunder yang terkandung dalam ekstrak etanol mikroalga Spirulina platensis seperti alkaloid, triterpenoid dan steroid, saponin, fenol, flavonoid dan kuinon; dan (2) mengetahui potensi kandungan di dalam ekstrak etanol mikroalga Spirulina platensis sebagai antibakteri dilihat berdasarkan kandungan golongan senyawa metabolit sekunder yang telah diketahui. Prosedur penelitian ini meliputi: determinasi spesies mikroalga, ekstraksi dengan metode maserasi dengan pelarut etanol, evaporasi pelarut serta analisis deskriptif mengenai potensi antibakteri. Mikroalga yang digunakan dalam penelitian ini adalah Sprulina platensis Geitler. Hasil penelitian menunjukkan bahwa: (1) golongan senyawa metabolit sekunder yang terkandung dalam ekstrak etanol mikroalga Spirulina platensis adalah golongan senyawa alkaloid, saponin, fenol dan kuinon; dan (2) kandungan golongan senyawa alkaloid, saponin, fenol dan kuinon dalam ekstrak etanol mikroalga Spirulina platensis menunjukkan adanya potensi mikroalga ini sebagai sumber bahan alam yang mengandung senyawa antibakteri.
\end{abstract}

Kata kunci: skrining fitokimia, mikroalga, Spirulina platensis, potenti antibakteri

\section{PENDAHULUAN}

Kandungan senyawa antibakteri dapat ditemukan hampir di setiap organisme baik yang berasal dari darat maupun dari perairan laut. Kandungan golongan senyawa metabolit sekunder diduga menjadi sumber senyawa antibakteri di alam, misalnya mikroalga. Mikroalga merupakan organisme fotosintesis mikroskopik yang ditemukan di lingkungan perairan dan laut (Demirbas \& Demirbas, 2010). Mikroalga diketahui memproduksi metabolit intraseluler dan ekstraseluler yang memiliki aktivitas biologi sebagai antialga, antivirus, antifungi dan antibakteri. Salah satu mikroalga tersebut adalah mikroalga Spirulina platensis.

Spirulina platensis merupakan salah satu jenis mikroalga autotrof hijau biru yang termasuk dalam kelas cyanobacteria. Secara mikroskopik, Spirulina platensis tampak seperti benang tipis (filamen) yang berbentuk spiral (Vonshak, 2002). Filamen ini merupakan koloni sel yang bergerak. Mikroalga ini berukuran panjang 200-300 dan lebar 5-70 mikron, berdiameter 1-12 
mikrometer, serta tidak memiliki inti sel (Oliveira dkk., 1999; Vonshak, 2002).

Spirulina platensis memiliki waktu panen yang sangat singkat. Mikroalga biasanya menggandakan diri dalam 24 jam. Alga ini terpengaruh oleh kondisi lingkungan yang fluktuatif, terutama suhu. Suhu optimal agar Spirulina platensis dapat tumbuh berkisar antara 30 sampai $35{ }^{\circ} \mathrm{C}$. Pada suhu antara $20-40{ }^{\circ} \mathrm{C}$, kandungan lipid Spirulina platensis dapat mencapai 6-7\% lipid (Oliveira dkk., 1999). Karakteristik kondisi lingkungan untuk tempat hidup Spirulina platensis tersebut sesuai dengan kondisi cuaca di Indonesia.

Fahleny dkk., (2014) melaporkan hasil pengujian antioksidan pada ekstrak Spirulina platensis memiliki nilai $\mathrm{IC}_{50} 288,68$ ppm. Kandungan metabolit sekunder lain yang berpotensi sebagai antibakteri juga perlu dicari di dalam mikroalga Spirulina platensis. Berdasarkan uraian tersebut, maka penelitian ini bertujuan untuk mengetahui golongan senyawa metabolit sekunder yang terkandung dalam ekstrak etanol mikroalga Spirulina platensis seperti alkaloid, triterpenoid dan steroid, saponin, fenol, flavonoid dan kuinon; serta mengetahui potensi ekstrak etanol mikroalga Spirulina platensis sebagai antibakteri dilihat berdasarkan kandungan golongan senyawa metabolit sekunder yang telah diketahui.

\section{METODE PENELITIAN}

Penelitian ini dilakukan di Laboratorium Kimia, Fakultas IImu Kesehatan, Universitas Muhammadiyah Palangkaraya. Penelitian ini meliputi ekstraksi dengan metode maserasi, evaporasi pelarut dan analisis deskriptif.

\section{Bahan penelitian}

Bahan-bahan yang digunakan dalam penelitian ini meliputi: mikroalga Sprulina platensis Geitler (dibeli dari CV. Blue Green Algae Biotechnology, Lamongan, Jawa Timur), akuades, kertas saring mikrofiber 90 $\mathrm{mm}$ (Fisher Bioblock), alumunium foil, magnesium (Mg) dan bahan-bahan pro analisis merk MERCK seperti asam sulfat $\left(\mathrm{H}_{2} \mathrm{SO}_{4}\right)$, pereaksi Dragendorff, pereaksi Meyer, kloroform, anhidrat asetat, asam klorida $(\mathrm{HCl})$, Besi(III) klorida $\left(\mathrm{FeCl}_{3}\right)$, natrium hidroksida $(\mathrm{NaOH})$ dan etanol.

\section{Alat penelitian}

Alat-alat yang digunakan dalam penelitian ini meliputi: tabung reaksi, gelas beker 500 $\mathrm{mL}$, pipet tetes, labu bundar, corong, neraca analitik, statif, pengaduk, kaca arloji, termometer, gelas ukur, pipet volume, vial kaca dan rotary evaporator.

\section{Ekstraksi mikroalga Spirulina platensis}

Sampel uji dari serbuk biomassa mikroalga Spirulina platensis diekstraksi secara maserasi (perendaman), dengan perbandingan $1: 10$ yaitu 1 bagian serbuk sampel mikroalga Spirulina platensis direndam dalam 10 bagian larutan etanol 
95\%. Maserasi dilakukan selama 5 hari dalam wadah berbahan gelas yang bermulut lebar dan setiap hari dikocok beberapa menit, kemudian disaring dengan kertas saring Whatman. Kemudian dilakukan penguapan/evaporasi dengan alat rotary evaporator pada suhu didih etanol sampai diperoleh ekstrak pekat.

\section{Skrining fitokimia ekstrak etanol} mikroalga Spirulina platensis

Analisis fitokimia yang dilakukan meliputi uji alkaloid, triterpenoid dan steroid, saponin, fenol, flavonoid dan kuinon. Metode analisis yang di gunakan berdasarkan pada Harborne (1987).

\section{Alkaloid}

Uji alkaloid dilakukan dengan melarutkan dalam beberapa tetes asam sulfat $2 \mathrm{~N}$ kemudian diuji dengan 2 pereaksi alkaloid yaitu pereaksi Dragendorff dan pereaksi Meyer. Hasil uji positif diperoleh bila terbentuk endapan merah hingga jingga dengan pereaksi Dragendorff dan endapan putih kekuningan dengan pereaksi Meyer.

\section{Triterpenoid dan steroid}

Sejumlah sampel dilarutkan dalam $2 \mathrm{~mL}$ kloroform dalam tabung reaksi yang kering lalu ditambahkan 10 tetes anhidrat asetat dan 3 tetes asam sulfat pekat. Reaksi positif ditunjukkan dengan terbentuknya larutan berwarna merah untuk pertama kali kemudian berubah menjadi biru dan hijau.

\section{Saponin}

Saponin dapat dideteksi dengan uji busa dalam air panas. Busa yang stabil akan terus terlihat selama 5 menit dan tidak hilang pada penambahan 1 tetes $\mathrm{HCl} 2 \mathrm{~N}$ menunjukkan adanya saponin.

\section{Fenol}

Sejumlah sampel diekstrak dengan $20 \mathrm{~mL}$ etanol $70 \%$. Larutan yang dihasilkan diambil sebanyak $1 \mathrm{~mL}$ kemudian ditambahkan 2 tetes larutan $\mathrm{FeCl}_{3} \quad 5 \%$. Reaksi positif ditunjukkan dengan terbentuknya warna hijau atau hijau biru.

\section{Flavonoid}

Sejumlah sampel ditambahkan serbuk magnesium $0,1 \mathrm{mg}$ dan $0,4 \mathrm{~mL}$ amil alkohol (campuran asam klorida $37 \%$ dan etanol $95 \%$ dengan volume yang sama) dan $4 \mathrm{~mL}$ alkohol kemudian campuran dikocok. Reaksi positif ditunjukkan dengan terbentuknya warna merah, kuning atau jingga pada lapisan amil alkohol.

\section{Kuinon}

Sejumlah sampel ditambahkan $\mathrm{NaOH} 1 \mathrm{~N}$ kemudian diamati perubahan warnanya. Reaksi positif ditunjukkan dengan terbentuknya warna kuning.

\section{HASIL DAN PEMBAHASAN}

\section{Ekstraksi mikroalga Spirulina platensis}

Ekstraksi dilakukan dengan metode maserasi dengan menggunakan pelarut etanol. Tujuan metode maserasi agar zat 
Skrining Fitokimia Ekstrak Etanol Mikroalga Spirulina platensis yang Berpotensi sebagai

Antibakteri

aktif yang berada di dalam sel Spirulina

platensis akan larut, sehingga akan

terdesak keluar dari sel. Hasil maserasi

disaring dengan menggunakan kertas

saring dan dihasilkan $300 \mathrm{~mL}$ filtrat. Filtrat

yang diperoleh kemudian dipekatkan.

Ekstrak etanol mikroala Spirulina platensis

yang diperoleh berupa ekstrak pekat berwarna ungu gelap.

\section{Skrining fitokimia ekstrak etanol \\ mikroalga Spirulina platensis}

Pada penelitian ini, pengujian secara kualitatif dilakukan untuk mengetahui jenis golongan senyawa bioaktif yang terkandung dalam ekstrak etanol kasar mikroalga Spirulina platensis, yaitu alkaloid, triterpenoid dan steroid, saponin, fenol, flavonoid dan kuinon. Hasil skrining fitokimia terhadap ekstrak etanol kasar mikroalga Spirulina platensis disajikan pada Tabel 1.

Tabel 1 Hasil skrining fitokimia terhadap ekstrak mikroalga Spirulina platensis

\begin{tabular}{lll}
\hline No. & Golongan Senyawa & Hasil \\
\hline 1 & Alkaloid & + \\
2 & Triterpenoid dan steroid & - \\
3 & Saponin & + \\
4 & Fenol & + \\
5 & Flavonoid & - \\
6 & Kuinon & + \\
\hline
\end{tabular}

Keterangan:

$+=$ mengandung senyawa yang diuji

- $\quad$ = tidak mengandung senyawa yang diuji

Hasil skrining fitokimia terhadap ekstrak etanol Spirulina platensis menunjukkan bahwa golongan senyawa yang terkandung dalam ekstrak tersebut adalah alkaloid, saponin, fenol dan kuinon.

Pada pengujian golongan senyawa alkaloid dilakukan penambahan asam klorida sebelum ditambahkan pereaksi karena alkaloid bersifat basa sehingga diekstrak dengan pelarut yang mengandung asam (Harborne, 1996). Hasil positif pada uji ini ditandai dengan terbentuknya endapan dari penggantian ligan. Atom nitrogen yang mempunyai pasangan elektron bebas pada alkaloid mengganti ion iod dalam pereaksi Dragendorff dan Mayer (Sangi, dkk., 2008). Pengujian golongan senyawa alkaloid pada ekstrak Spirulina platensis menunjukkan hasil positif pada uji Mayer, namun negatif pada uji Dragendorff. Dengan pereaksi Mayer diperoleh larutan berwarna putih sesuai reaksi berikut. 


$$
\mathrm{HgCl}_{2}+2 \mathrm{KI} \longrightarrow \mathrm{HgI}_{2}+2 \mathrm{KCl}
$$

Pengujian golongan senyawa

alkaloid pada ekstrak Spirulina platensis menunjukkan hasil negatif pada uji Dragendorff. Pada uji Dragendorff tidak menyebabkan terbentuknya endapan jingga pada penambahan pereaksi Dragendorff dimungkinkan sedikit mengandung alkaloid.

Saponin merupakan senyawa yang mengandung gugus hidrofilik dan juga gugus hidrofobik. Bila suatu ekstrak yang mengandung golongan saponin digojok, maka terbentuk buih/busa yang disebabkan adanya gugus hidrofilik yang berikatan dengan air sedangkan gugus hidrofobik akan berikatan dengan udara. Pada struktur misel, gugus polar menghadap ke luar sedangkan gugus non-polar menghadap ke dalam. Penambahan $\mathrm{HCl} 2 \mathrm{~N}$ bertujuan untuk menambah kepolaran sehingga gugus hidrofilik akan berikatan lebih stabil dan buih yang terbentuk menjadi stabil (Kumalasari dan Sulistyani, 2011). Berdasarkan hasil penelitian, ekstrak etanol mikroalga Spirulina platensis menunjukkan hasil positif yang berarti bahwa ekstrak ini mengandung saponin.
Pereaksi besi(III) klorida $\left(\mathrm{FeCl}_{3}\right)$ digunakan secara luas untuk identifikasi senyawa fenol/polifenol/tanin. Pengujian fenol menunjukkan hasil positif bila menghasilkan warna biru tua, biru kehitaman atau hitam kehijauan. Perubahan warna terjadi dengan penambahan $\mathrm{FeCl}_{3}$ karena adanya gugus hidroksil (Sangi dkk., 2013; Artini dkk., 2013). Pada uji keberadaan fenol menunjukkan bahwa ekstrak etanol mikroalga Spirulina platensis mengandung golongan senyawa fenol. Perkiraan reaksi dalam uji golongan senyawa fenol sebagai berikut:

$\mathrm{FeCl}_{3}$
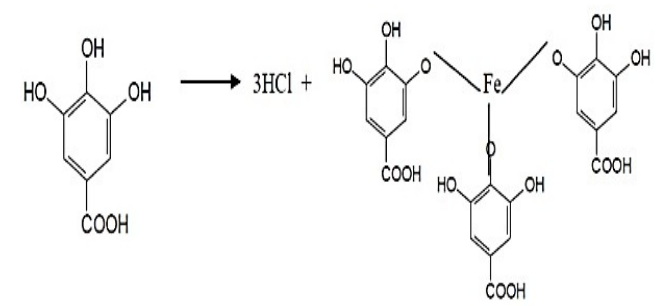

Uji keberadaan kuinon dapat dilakukan dengan reaksi warna. Salah satu cara untuk mendeteksi kuinon dapat digunakan pereaksi larutan natrium hidroksida $1 \mathrm{~N}$. Bila terbentuk wama merah atau kuning menunjukkan adanya kuinon Harborne (1987). Berdasarkan hasil penelitian, ekstrak etanol mikroalga Spirulina platensis mengandung adanya kuinon dengan menunjukkan uji positif.

\section{Potensi Ekstrak Mikroalga Spirulina platensis sebagai antibakteri}


Skrining Fitokimia Ekstrak Etanol Mikroalga Spirulina platensis yang Berpotensi sebagai

Antibakteri

Berdasarkan kandungan senyawa metabolit

sekunder tersebut, dapat ditelusuri potensinya sebagai antibakteri dengan mengulas tentang mekanisme bagaimana golongan senyawa tersebut bekerja sebagai antibakteri.

Menurut Darsana dkk. (2012), mekanisme kerja alkaloid sebagai antibakteri yaitu dengan cara mengganggu komponen penyusun peptidoglikan pada sel bakteri, sehingga lapisan dinding sel tidak terbentuk secara utuh dan menyebabkan kematian sel tersebut. Mekanisme lain antibakteri alkaloid yaitu komponen alkaloid diketahui sebagai interkelator DNA dan menghambat enzim topoisomerase sel bakteri (Karou dkk., 2005).

Mekanisme kerja senyawa golongan saponin sebagai antibakteri yaitu dapat menyebabkan kebocoran protein dan enzim dari dalam sel (Madduluri dkk., 2013). Saponin dapat menjadi antibakteri karena zat aktif permukaannya mirip detergen, akibatnya saponin akan menurunkan tegangan permukaan dinding sel bakteri dan merusak permeabialitas membran. Rusaknya membran sel ini sangat mengganggu kelangsungan hidup bakteri (Harborne, 1987). Saponin berdifusi melalui membran luar dan dinding sel yang rentan kemudian mengikat membran sitoplasma sehingga mengganggu dan mengurangi kestabilan membran sel. Hal ini menyebabkan sitoplasma bocor keluar dari sel yang mengakibatkan kematian sel. Agen antimikroba yang mengganggu membran sitoplasma bersifat bakterisida (Cavalieri dkk., 2005).

Mekanisme antibakteri senyawa fenol dalam membunuh mikroorganisme menurut Palczar dan Chan (1988) yaitu dengan mendenaturasi protein sel. Ikatan hidrogen yang terbentuk antara fenol dan protein mengakibatkan struktur protein menjadi rusak. Ikatan hidrogen tersebut akan mempengaruhi permeabilitas dinding sel dan membran sitoplasma sebab keduanya tersusun atas protein. Permeabilitas dinding sel dan membran sitoplasma yang terganggu dapat menyebabkan ketidakseimbangan makromolekul dan ion dalam sel, sehingga sel menjadi lisis.

Sementara senyawa kuinon akan berikatan dengan protein dan membuat rangkaian kompleks dengan asam amino sehingga mengganggu metabolisme sel bakteri dan menyebabkan protein kehilangan fungsinya (Putra, 2010; Cowan, 1999).

\section{KESIMPULAN}

Berdasarkan pembahasan di atas, dapat ditarik kesimpulan sebagai berikut:

1. Golongan senyawa metabolit sekunder yang terkandung dalam ekstrak etanol mikroalga Spirulina platensis adalah alkaloid, saponin, fenol dan kuinon. 
2. Kandungan golongan senyawa alkaloid, saponin, fenol dan kuinon dalam ekstrak etanol mikroalga Spirulina platensis menunjukkan potensi mikroalga Spirulina platensis sebagai sumber bahan alam yang mengandung senyawa antibakteri.

\section{UCAPAN TERIMA KASIH}

Penulis mengucapkan terima kasih kepada Lembaga Penelitian dan Pengabdian kepada Masyarakat (LP2M) Universitas Muhammadiyah Palangkaraya yang telah mendanai penelitian ini.

\section{DAFTAR PUSTAKA}

1. Artini, P.E.U.D., Astuti, K.W., dan Warditiani, N.K., 2013. Uji fitokimia ekstrak etil asetat rimpang bangle (Zingiber purpureum Roxb.), Jurnal Farmasi Udayana.

2. Cavalieri, S.J., I.D. Rankin., R.J. Harbeck., R.S. Sautter., Y.S. McCarter., S.E. Sharp., J.H. Ortez., dan C.A. Spiegel. 2005. Manual of Antimicrobial Susceptibility Testing. USA: American Society for Microbiology.

3. Cowan, M.M. 1999. Plant Product as Antimicrobial Agents, Clinical Microbiology Reviews. 12(4): 564-582.

4. Darsana, I. Besung, I. Mahatmi, H. 2012. Potensi Daun Binahong (Anredera Cordifolia (Tenore) Steenis) dalam Menghambat Pertumbuhan Bakteri Escherichia coli secara In Vitro. Indonesia Medicus Veterinus.

5. Demirbas, A. dan Demirbas, M.F., 2010, Algae Energy: Algae as a new source of biodiesel, Springer-Verlag, London.

6. Fahleny, R., Trilaksani, W., dan Setyaningsih, I., 2014, Aktivitas antioksidan pada formula terpilih tablet hisap Spirulina platensis berdasarkan karakater fisik, Jurnal IImu dan Teknologi Kelautan Tropis, 6 (2): 427444.

7. Harborne, J. B., 1987, Metode Fitokimia: Penuntun Cara Modern Menganalisis Tumbuhan, Diterjemahkan oleh Kosasih Padmawinata dan Iwang Soediro, Institut Teknologi Bandung, Bandung.

8. Karou, Damintoti. Savadogo. Aly. 2005. Antibacterial activity of alkaloids from Sida acuta. African Journal of Biotechnology. 4(12): $1452-1457$.

9. Kumalasari, E. dan N. Sulistyani. 2011. Aktivitas Antifungi Ekstrak Etanol Batang Binahong (Anredera cordifolia (Tenore) Steen.) Terhadap Candida albicans serta Skrining Fitokimia. Jurnal IImiah Kefarmasian, 1 (2): 51 62.

10. Lehninger, A. L., 1982. Principles of Biochemistry. Worth Publishers. New York.

11. Madduluri, Suresh. Rao, K. Babu. Sitaram, B. 2013. In Vitro Evaluation of Antibacterial Activity of Five Indegenous Plants Extract Against Five Bacterial Pathogens of Human. International Journal of Pharmacy and Pharmaceutical Sciences. 5(4): 679684.

12. Oliveira, M.A.C.L.D., Monteiro, M.P.C., Robbs, P.G. dan Leite, S.G.F., 1999, Growth and chemical composition of Spirulina maxima and Spirulina platensisbiomass at different temperatures, Aquac Int., 7, 261-275.

13. Palczar, J.M dan Chan, E.C.S. Dasardasar Mikrobiologi 2. Jakarta: Penerbit UI Press. 1988.

14. Putra, I.N.K. 2010. Aktivitas Antibakteri Ekstrak Kulit Buah manggis (Garcinia Mangostana L.) Serta Kandungan Senyawa Aktifnya, J Teknol Industri Pangan. 21: 1-5.

15. Sangi, M.S., Momuat, L.I. dan Kumaunang, M., 2013. Uji toksisitas dan skrining fitokimia tepung gabah pelepah aren (Arange pinnata). Manado: Universitas Sam Ratulangi. 
Skrining Fitokimia Ekstrak Etanol Mikroalga Spirulina platensis yang Berpotensi sebagai

Antibakteri

16. Sangi, M., M.R.J. Runtuwene., H.E.I. Simbala., V.M.A. Makang. 2008. Analisis Fitokimia Tumbuhan Obat di kabupaten Minahasa Utara. Chem. Prog, 1(1):47-53.
17.Vonshak, A., 2002, Spirulina platensis (Arthrospira): Physiology, cell-biology and biotechnology, Taylor \& Francis Ltd., London. 